\title{
Bir Emevî Komutanı Tipolojisi Olarak Husayn b. Nümeyr es-Sekûnî el-Kindî
}

\section{Fatih Zengin*}

Atıf/C: Zengin, Fatih, Bir Emevî Komutanı Tipolojisi Olarak Husayn b. Nümeyr es-Sekûnî el-Kindî, Artuklu Akademi, 2021/8 (1),1-27.

Öz: Bu makale, Emevî Devleti'nin isyanlarla başa çıkmasında kilit roller üstlenen bir komutanı literatür taraması yöntemiyle ele almaktadır. Kinde kabilesinin ileri gelen isimlerinden olan Husayn b. Nümeyr, Muâviye döneminden itibaren Emevîler'e sadakatle hizmet etmiştir. Muâviye ve Yezîd dönemlerinde Rumlar üzerine yapılan yaz seferlerine Humus ordugahı komutanı olarak iştirak etmiştir. İslam tarihine geçen birçok faciada ön saflarda olan Husayn, Hz. Hüseyin'in şehid edilmesinde, Harre Vakasında, Abdullah b. Zübeyr'in ilk kuşatılması ve Kâbe'nin yanması olayında ve son olarak Tevvabîn hareketinin bastırılmasında önemli rol oynamıştır. Yezîd b. Muâviye'nin en güvendiği isimlerden olan Husayn, Emevîler'e karşı başlatılan isyanların hemen tamamında görevlendirilen komutanlardan biri olmuştur.

Anahtar Kelimeler: İslam Tarihi, Husayn b. Nümeyr, Yezîd b. Muâviye, Harre, Kerbelâ.

\section{Husayn ibn Numayr as-Sakuni al-Kindi as an Umayyad Commander Typology}

Citation/(: Zengin, Fatih, Husayn ibn Numayr as-Sakuni al-Kindi as a Umayyad Commander Typology, Artuklu Akademi, 2021/8 (1),1-27.

\begin{abstract}
Through a literature review, this article discusses activities of a commander who played a key role in the Umayyad State's overcoming the rebellions. Husayn b. Numayr (d. 67/686) is one of the leading names of Kindah tribe. He faithfully served the Umayyads as of the Muawiya's (d.60/680) tenure. He participated in the summer expeditions against Greeks during the Muawiya and Yazid (d.64/683) periods as the commander of the military camp of Homs. Ibn Numayr as- Sakuni, who was crusading at the forefront of many conflicts in the history of Islam, played an important role in the martyrdom of Husayn ibn Ali (d. 61/680), the first siege of Abdullah b. Zubayr and the burning of the Kaaba, and finally the suppression of the Tawwabun movement. Husayn is one of the people that Yazid b. Muawiya trusts most. For this reason, he was one of the commanders assigned to counteract almost all of the rebellions against the Umayyads.
\end{abstract}

\footnotetext{
Dr. Öğr. Üyesi, İnönü Üniversitesi İlahiyat Fakültesi İslam Tarihi Anabilim Dalı,
} fatih.zengin@inonu.edu.tr 
Keywords: Islamic History, Husayn b. Numayr, Yazid ibn Mu'awiya, Battle of al-Harra, Battle of Karbala.

\section{Giriş}

Emevî Devleti'nin kurulması, Hz. Osman'ın hilafeti döneminde Ümeyyeoğulları ailesinin devletin birçok kademesinde görevlendirilmesiyle başlayan, Muâviye b. Ebû Süfyân'ın Hz. Ali'ye karşı girişmiş olduğu siyasî mücadele ile tamamlanan bir sürecin sonucudur. Hz. Osman'in şehid edilmesini merkeze alarak Hz. Ali'ye karşı çıkan Muâviye, zamanla iddiasını hilafet meselesine dönüştürmüştür. ${ }^{1}$ Akabinde cereyan eden Siffîn ve ardından yaşanan tahkîm olaylarıyla kendi taraftarları arasındaki meşruiyet algısını da güçlendirmiştir. Muâviye, Hz. Ali'nin vefatı ve Hz. Hasan'ın da hilafetten feragat ederek ona biat etmesiyle İslam devletindeki tek halife olmuştur. Bu mücadelelerde Muâviye b. Ebû Süfyân'ın kişiliği, kararlılı̆̆ı, insanî ve iktisâdî imkanlarını etkili kullanma becerisi ve sonuç almaya yönelik siyaset anlayışı Emevî Devleti'nin tarih sahnesine çıkmasını sağlamıştır.

Muâviye'nin, siyasî başarısının dayandı̆̆ı en ayırt edici yönlerinden birisi yetenekli devlet adamlarını her yolu deneyerek kendi hizmetine alma becerisidir. Bu politikasının bir yansıması olarak Amr b. el-Âs, Muğîre b. Şu'be ve Ziyâd b. Ebîh gibi Arap siyaset dâhilerini Emevî Devleti'nin hizmetine almıştır. ${ }^{2}$ Mümkün olan en fazla sayıda insanın desteğini almak için her yolu deneyen Muâviye, muarızlarını kazanmaya çabalamakla kalmamıs, bunun yanı sıra taraftarlarının da desteğini sürekli hale getirmeye çalışmıştır. Muâviye'nin bu politikası, sonraki Emevî halifelerinin de bir şekilde uymaya çalıştıkları bir usul haline gelmiştir. ${ }^{3}$

Şüphesiz yukarıda adı geçenler dışında da gerek Şam'dan gerekse başka bölgelerden pek çok önemli isim Muâviye'nin mücadelesi sırasında ona destek olmuşlardır. Bunlardan birisi de Şam dolaylarına yerleşmiş olan

Muaviye'nin iddialarını siyasî alana destek yapma çabaları üzerine değerlendirmeler için bkz. Adnan Demircan, Ali-Muaviye Kavgası (İstanbul: Beyan Yayınları, 2014), 74 vd.

2 Muhammed b. İsmail b. İbrâhîm Buhârî, et-Tarihü'l-kebir. (Haydarabad: Dairetü'l-Maarif el-Osmaniyye, tsz.), VII, 316; Muâviye'nin Amr b. el-As'ı yanında tutmak için verdiği tavizler için bkz. Adem Apak, İslâm Siyaset Geleneğinde Amr b. el-Âs (Ankara: Ankara Okulu Yayınları, 2001), 135-36.

3 Bu çerçevede Yezîd b. Muâviye'nin Ubeydullah b. Ziyad'1 Kerbelâ hadisesinden kaynaklanan bütün tepkilere rağmen görevden almaması ile Abdülmelik b. Mervan ve ondan sonra gelen Velid $b$. Abdülmelik'in Haccac b. Yusuf'a yönelik şikâyetlerine rağmen onu Irak valiliğinde tutması örnek gösterilebilir. Ebu Muhammed Abdullah b. Müslim b. Kuteybe ed-Dineverî, el-Maarif (el-Hey'etü'l-Mısriyye elAmme li'l-Kütüb, 1992), 347; Ebû'l-Fadl Ahmed b. Ali b. Muhammed İbn Hacer el-Askalanî, Tehzîbu't-tehzîb (Hind: Matbaatü Daireti'l-Maarif en-Nizamiyye, 1908), II, 210. 
Kinde kabilesinin ileri gelenlerinden Husayn b. Nümeyr el-Kindî esSekûnî'dir. Husayn, tipik bir Emevî komutanı olarak kendinden önceki Ziyâd b. Ebîh ile dönemindeki Ubeydullah b. Ziyâd ve Şemr b. Zilcevşen gibi askerlerin acımasızlık, Emevî halifelerine bağlılık gibi karakteristik özelliklerini taşırken, kendinden sonra gelecek olan Haccac b. Yusuf gibi vali-komutanların da öncülerinden olmuştur.

Halifelerin politikalarının uygulanabilmesi, hiç şüphesiz ki bu politikaları icra eden valiler, vergi memurları ve komutanlar gibi devlet adamlarının yetenekleri ve uygulamada gösterdikleri çaba ile yakından alakalıdır. Bu makalede Emevî tarihindeki rolü üzerinde durulan Husayn b. Nümeyr, özellikle Yezîd dönemi için bu anlamda çok kritik öneme sahip isimlerden biridir. Tespitlerimize göre, ülkemizde şu ana kadar hakkında müstakil bir çalışmanın yapılmamış olması, kanaatimce müdahil olduğu olayların büyüklüğünün gölgesinde kalmış olmasından kaynaklanmaktadır. Her biri ayrı bilimsel çalışma konusu olabilecek olan bu hadiseler o denli büyüktür ki onların sebepleri ve sonuçlarıyla ilgili çalışmalar yapılmasından Husayn b. Nümeyr ismi adeta unutulmuştur. Bu nedenle Husayn ismi ile ilgili bir çalışma yapılmasının Yezîd başta olmak üzere erken dönem Emevî idarecileri ile toplum arasındaki ilişkilerin anlaşılmasına katkı sağlayacağ1 kanaatini taşıyoruz.

Husayn b. Nümeyr'in ismi özellikle tarih ve ensâb kitaplarında geçmektedir. Doğrudan tarih alanında yazılmamış eserlerde ise genellikle Kâbe'nin yanması hadisesi nedeniyle zikredilmektedir. Hadis kitaplarında Kâbe'nin gelecekte saldırıya uğrayacağına dair rivayetler ekseninde, fikıh kitaplarında ise Harem'de yasak olan davranışlar ve Kâbe ile ilgili diğer hükümler çerçevesinde Husayn b. Nümeyr'den söz edilmektedir.

\section{Kinde'nin Devlet Tecrübesinin Vârisi; Husayn b. Nümeyr}

Husayn b. Nümeyr b. Üsâme b. Züheyr b. Düreyd b. Cüşeyş b. Malik b. Hanzale b. Zeyd Menât b. Temîm, ${ }^{4}$ Arapların önemli kabilelerinden

\footnotetext{
Ebu Muhammed Ali b. Ahmed b. Said el-Endelüsî İbn Hazm, Cemheretü ensâbi 'l-arab (Beyrut: Dârü'l-Kütübü'lİlmiyye, 1983), 228. Husayn b. Nümeyr'in hadis rivayetiyle ilgisi olmadığı halde bazı müellifler onu Bilâl-i Habeşî́den hadis rivayet eden, aynı adı taşıyan râvi ile karıştırmışlardır. Ancak Emevî komutanı olan Husayn b. Nümeyr'in hadis rivayet ettiğine dair ulaşabildiğimiz bir bilgi mevcut değildir. Hadis râvîsi olan İbn Nümeyr'in nisbesi ise Vâsıtî́dir. Bkz. Buhârî, et-Tarihü'l-kebir, VI, 90. Aynı şekilde Hz. Peygamber'in kâtipleri arasında adı geçen Husayn b. Nümeyr'in de Emevî komutanı Husayn b. Nümeyr ile bir ilgisi bulunmamaktadır. Bu üçüncü Husayn'ın nesebi bilinmemektedir. Sadece onun bazı rivayetleri ve Medine'de Muğire $b$. Şu'be ile birlikte insanların borçlarını ve diğer sözleşmelerini kaydettiği bilinmektedir. Bu anlamda İslam tarihinde ilk noterlik faaliyetini bunlar yürütüyorlardı. Ebû'lFadl Ahmed b. Ali b. Muhammed İbn Hacer el-Askalanî, Tehzîbu't-tehzîb, II, 392; M. Mustafa el-A'zamî, Küttâbu'n-nebi (Beyrut: el-Mektebü'l-İslamî, 1978), 46; Ebû Abdullah Muhammed b. Ali b. Ahmed b. Hadide el-
} 
Kinde'ye mensuptur. Nisbesi kaynakların çoğunda Sekûnî olarak yer

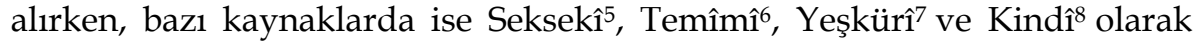
kaydedilmektedir. Bir yerde de Selûlî̀ ${ }^{9}$ olarak geçmektedir ki bunun nedeni Sekûnî yazılması gerekirken yapılan bir yazım hatası olabilir. Kaynaklarda Husayn'ın doğum tarihine dair bir bilgiye ulaşamadık. Dolayısıyla onun kaç yaşında vefat ettiğine dair isabetli bir tahmin yürütme imkanımız bulunmamaktadir.

Arabistan'da bir devlet kurma ve uzun bir müddet (480-525) bunu yaşatma yeteneği gösteren Kinde kabilesi, Yemen ve Orta Arabistan' da geniş bir bölgede yaşamıştır. Kabile mensupları sonraki dönemlerde Suriye ve Irak'a da yayılmışlar ancak burada uzun süreli ve kalıcı olamamışlardır. Başlangıçta Yemen'deki Himyer devletine bağlı bir emirlik olarak varlıklarını sürdürmüş ancak zamanla daha özerk bir yapı kazanarak güçlenmişler ve bir devlet halini almışlardır. Kinde Devleti Irak'taki Sâsânî tebaası olan Hîre devletiyle girdikleri savaşlarda mağlup olması üzerine yıkılmıştır (525). Ancak nüfuslarının çokluğu ve pek çok boydan oluşmaları nedeniyle devletlerinin yıkılmasına rağmen kabile olarak varlıklarını ve ehemmiyetlerini sürdürmüşlerdir. Kindeliler, Hz. Peygamber'in Mekke'de kabileleri İslam'a davet ettiği dönemde tebliğe muhatap olmuşlarsa da olumlu yanıt vermemişler, hicrî 9. yıla (Senetü'l-Vüfûd/Heyetler Yılı) kadar da kitlesel olarak Müslüman olmamışlardır. ${ }^{10}$

Kindeliler, Müslüman olduktan sonra ilk iki halife döneminde Arabistan'daki diğer kabileler gibi Suriye ve Irak'taki fetih hareketlerine katılmış ve fethedilen topraklara yerleşmişlerdir. Husayn b. Nümeyr'in mensubu olduğu Kinde'nin Sekûn kolu da Hadramut'tan Suriye'ye gelip

Ensârî İbn Hadîde, el-Misbâhü'l-mudi' fi küttâbi'n-nebiyyi'l-ümmî ilâ mülûki'l-arzi min arabi ve acemi (Beyrut: Alemu'l-Kütüb, tsz.), I, 85; Fahrettin Atar, "Noter", Türkiye Diyanet Vakfi İslam Ansiklopedisi (İstanbul: Türkiye Diyanet Vakfi, 2007), XXXIII, 210-213.

5 Muhammed b. Habîb b. Ümeyye b. Habîb, el-Muhabber (Beyrut: Darü'l-Afaki'l- Cedide, tsz.), 491; Muhammed b. Habib Ebu Cafer el-Bağdadî, el-Münemmak fi ahbari Kureyş (Beyrut: 'Alemu'l-Kütüb, 1985), 316. Bu nisbenin hatalı olması gerekir. Zira Seksek ve Sekûn Kinde'nin iki ayrı koludur.

6 İzzüddîn Alî b. Muhammed b. Muhammed eş-Șeybânî el-Cezerî İbnü'l-Esîr, el-Kâmil fi't-târîh (Beyrut: Dâru'lKitâbi'l-'Arabî, 1997), III, 150.

7 el-Makdisî, el-Mutahhar b. Tahir, el-Bed' ve 't-târîh (Port Said: Mektebetü's-Sekâfeti'd-Dîniyye, tsz.), VI, 14.

8 Ebü'l-Velîd Muhammed b. Abdullah el-Ezrakî, Ahbâru Mekke (Beyrut: Daru'l-Endelüs, tsz.), I, 64; Ebû Amr Halîfe b. Hayyat eş-Şeybânî Hayyat, Tarihu Halife b. Hayyat (Dımaşk, Beyrut: Daru'l-Kalem, 1976), 254.

9 Ebû Ali Ahmed b. Muhammed b. Yakub İbn Miskeveyh, Tecâribü'l-ümem ve te âkibü'l-himem (Tahran: Suruş, 2000), II, 89.

10 Ebu Abdullah Muhammed İbn İshak, Siretu İbn İshak (Beyrut: Daru'l-Fikr, 1978), 232. 
Ebû Ubeyde b. Cerrâh'ın komutası altında Humus'un fethine katılmış ve buraya yerleşmiştir. ${ }^{11}$

Husayn b. Nümeyr ve Sekûn kabilesi, atalarından miras aldıkları idarî-siyasî tecrübeyi Emevî Devleti'nin kurulmasıyla sergileme fırsatı bulmuşlardır. Zira ilk üç halife döneminde Medine, Hz. Ali döneminde de Kûfe başkent olduğu için bu dönemde Humus bölgesinde yerleşik olan Sekûn kabilesinin toprakları uzak bir taşra bölgesi idi. Emevî Devleti'nin Şam'1 merkez edinmesi, Kinde kabilesinin yeni neslinde devlet tecrübelerinin yeniden uyanmasını sağlamıştır. Dolayısıyla Husayn b. Nümeyr'in Muâviye b. Ebû Süfyân'ı desteklemesi de Yezîd döneminde Emevîler'in en önemli komutanlarından ve devlet adamlarından birisi olması da tesadüf değildir. Hem nüfusları hem de bir devlet geleneğine sahip olmaları, onları Emevî Devleti'nde önemli konumlara getirmiştir. Nitekim Sekûnîler ve Husayn b. Nümeyr'in soyundan gelenler Emevî tarihi boyunca bu özelliklerini korumuşlardır. Örneğin Husayn'ın oğlu Yezîd b. Husayn b. Nümeyr de önemli bir isim olarak Emevî Devleti'nde göze çarpmaktadır. Yezîd, babası Husayn ile birlikte savaşlara katılmış ve Velîd b. Abdülmelik (705-715) döneminde siyasî hayatta etkin olmuştur. ${ }^{12}$ Onun oğlu Muâviye b. Yezîd b. Husayn ise Süleyman b. Abdülmelik (715-717) döneminde Humus valisi olarak atanmış, ancak bir süre sonra görevinden azledilmiştir. ${ }^{13}$ II. Velîd'in öldürüldüğünü ve III. Yezîd'in hilafete geçtiğini öğrenen Humuslular III. Yezîd'e biat etmeyip Muâviye b. Yezîd b. Husayn'ın önderliğinde isyan ettiler. Ancak isyancılar Dımaşk civarında halifenin ordusuna mağlup oldular. Bunun üzerine Yezîd'e itaat ettiklerini bildiren Humuslular ve başlarındaki Muâviye b. Yezîd b. Husayn affedildiler ve Muâviye Humus valisi tayin edildi. Muâviye, Mervân b. Muhammed (744-750) dönemindeki iç karışıklıklar esnasında Humus askerleriyle birlikte halifenin emrine girmiştir. ${ }^{14}$

Görüldüğü gibi Kinde'nin Sekûn kolu Husayn b. Nümeyr döneminden beri Emevî devletinde önemli bir rol oynamıştır. Özellikle Humus ve civarının yönetimi neredeyse kesintisiz olarak bu kabilenin elinde olmuş ve kabilenin riyasetini de Husayn b. Nümeyr'in soyu yürütmüştür.

\footnotetext{
1 Ebû Abdullah Şemseddin Muhammed b. Ahmed b. Osman Zehebî, Tarihü'l-islâm ve vefeyatü'l-meşâhir ve'l-a'lâm (Beyrut: Daru'l-Kitabi'l-Arabi, 1993), III, 128.

12 Ahmed b. Yahyâ b. Câbir b. Dâvûd el-Belâzürî, Ensâbü'l-eşrâf, ed. Süheyl Zekkar ve Riyâd Zirikli (Beyrut: Dârü'lFikr, 1996), VIII, 87.

13 Belâzürî, Ensâbü'l-eşrâf, IX, 224.

14 Belâzürî, Ensâbü̈'l-eşrâf, IX, 9, 265; İbn Miskeveyh, Tecâribu 'l-ümem, III, 226.
} 


\section{Siyasî-Askerî Hayatı}

Kinde gibi çok büyük kabilelerin siyasî ihtilaflarda farklı tavırlar sergileyen boylarının olması son derece tabiidir. Çok geniş coğrafyalara yayılmış ve birbirinden farklı beklentiler içinde olan Kinde kolları da AliMuâviye ihtilafında ikiye ayrılmışlardır. Bir taraf Muâviye'yi desteklerken diğeri Hz. Ali'yi desteklemiştir. Husayn b. Nümeyr Humus'da yerleşmiş olan Kindeliler'le birlikte Siffîn savaşında Muâviye b. Ebû Süfyân'ın saflarında Hz. Ali'ye karşı mücadele etmiştir. Buna karşılık Husayn ve onu destekleyen Kindeliler, Emevî Devleti'nde bazı imtiyazlara sahip olmuşlardır. Örneğin Husayn b. Nümeyr, Mervân b. Hakem'e biat ederken Husayn ve onu destekleyen Kindeliler, Belkâ'nın Şam'da bulunan Kindeliler'e verilmesini şart koşmuştur. ${ }^{15}$

Muâviye b. Ebû Süfyân'ın hilafeti ele alıp konumunu güçlendirmesinin ardından yeniden düzenlenmeye başlanan Anadolu seferlerine Husayn b. Nümeyr de katılmıştır. Bu çerçevede Muâviye döneminde 58/678 yılında Rumlar üzerine gönderilen yaz seferini ${ }^{16}$ komuta etmiştir. ${ }^{17}$ Aynı zamanda Humus garnizonunun komutanı olan Husayn, Yezîd b. Muâviye döneminde de Bizans'a karşı düzenlenen yaz seferinde (62/682) ordu komutanı olarak görev aldı. ${ }^{18} \mathrm{~Hz}$. Osman'ın hilafetinin son altı yılında başlayan ve uzun bir süre devam eden iç sorunların çözüldüğ ü ve görece bir sükûnet ortamının oluştuğu Muâviye dönemi boyunca Husayn b. Nümeyr'in Emevî Devleti toprakları dâhilinde bir faaliyetine rastlanmamaktadır. Ancak Muâviye'nin vefatından sonra hilafete gelen Yezîd b. Muâviye döneminde Husayn b. Nümeyr, artık tam anlamıyla muhaliflere karşı verilen mücadelelerin merkezinde yerini alan önemli isimlerden biri olmuştur.

\section{Yezîd Dönemindeki Faaliyetleri}

Muâviye b. Ebû Süfyân, vefat etmeden önce yerine bir veliaht tayin etmeyi düşünmüş ve bu iş için de oğlu Yezîd'i uygun görmüştü. Bu kararına yönelik adımlar atmaya başlayınca, Suriye'deki pek çok Arap kabilesi gibi Sekûnîler de Yezîd'e biat etmekte gecikmediler. Muhtemelen Kinde boyları

15 Ebû Cafer İbn Cerir Muhammed b. Cerir b. Yezîd et-Taberî, Tarihü’t-Taberî (Beyrut: Daru’t-Türas, 1967), V, 544.

16 Çoğulu "savâif" olan bu seferler Hz. Ömer döneminden beri icra edilmekteydi. Daha geniş bilgi için bkz. Mustafa Sabri Küçükaşçı, "Savâif", Türkiye Diyanet Vakfi İslam Ansiklopedisi, (İstanbul: Türkiye Diyanet Vakfi, 2009), XXXVI, 185-186.

17 Hayyat, Tarihu Halife b. Hayyat, I, 225.

18 Hayyat, Tarihu Halife b. Hayyat, I, 236; Ebü’l-Kâsım Sikatüddin Ali b. Hasan b. Hibetullah İbn Asakir, Târîhu Dımaşk, (Beyrut : Dârü'l-Fikr, 1995), XIV, 385. 
eski bir devlet bakiyesi olarak zaten Hicaz'ın egemenliği altına girmektense yönetim merkezinin Şam'da bulunmasını yeğlemekteydiler. Bu bağlamda Husayn'ın Abdullah b. Zübeyr kuşatması sona erdikten sonra israrla onu Şam'a davet etmesi de böyle okunabilir. ${ }^{19}$ Nitekim bu politikanın bir sonucu olarak Husayn b. Nümeyr de ilk andan itibaren Yezîd'in veliahtlığına sağlam bir destek vermiş ve Muâviye'nin vefatından sonra Yezîd'e biat etmekte gecikmemiştir.

Güçlü bir komutan olması, Kinde kabilesinin bir boyu olan Sekûnîler'in riyasetini yürütmesi ve en önemlisi de iktidara gelmesine verdiği destek sayesinde Husayn, Yezîd nazarında önemli ölçüde itibar kazanmıştı. Hatta onun ricasıyla Ubeydullah b. Ziyâd'ın hapsettiği şair İbn Müferriğ, Yezîd'in talimatıyla serbest bırakılmıştır. Ubeydullah b. Ziyâd gibi ismi Emevî tarihiyle özdeşleşmiş bir vali/komutana rağmen Yezîd'in, Husayn'ın talebini yerine getirmesi onun Yezîd'in yanındaki değerini göstermektedir. Benzer şekilde başka bir şair hakkında verilecek hüküm konusunda da Husayn'ın Yezîd'e görüş belirtebilecek düzeydeki kimselerden olduğu anlaşılmaktadır. Abdurrahman b. Hassan b. Sabit'in Yezîd'den gördüğ̈ü kötü muamele yüzünden onu hicvetmesi üzerine Husayn b. Nümeyr (ya da Müslim b. Ukbe) Yezîd'e “Onu öldür! Çünkü Emîru'l-Müminin Muâviye'nin yumuşaklığı bunları sana karşı cüretkar kıldı" demiştir. Buna karşılık Yezîd "Biz onu kovduk ve aşağıladık, dolayısıyla bizi hicvetmesini hak ettik" demiş ve ona otuz bin dirhem göndermiştir. ${ }^{20}$

Günümüz hükümetleri gibi Emevîler döneminde de idarecilerin tayin etmiş olduğu isimler sadece kendilerini değil tayin eden yöneticiyi de temsil ediyordu. Bu nedenle aşağıdaki olaylarda tasarrufları aktarılacak olan Husayn b. Nümeyr'in, emri altında görev yaptı̆̆ı Yezîd b. Muâviye, Mervân b. Hakem ve Abdülmelik b. Mervân'ı temsilen de bu işlere giriştiği bir vakıadır. Tıpkı Hz. Osman'ın tayin ettiği valilerin icraatlarının ona karşı kullanılması gibi Husayn b. Nümeyr'in faaliyetleri de Ubeydullah b. Ziyâd gibi valiler ve Müslim b. Ukbe gibi komutanların da yönetim anlayışını ve toplumsal karşılıklarını göstermektedir. ${ }^{21}$

\footnotetext{
19 Ebû Abdullah Muhammed b. Sa'd b. Meni' ez-Zührî İbn Sa'd, et-Tabakâtü 'l-kübrâ, ; (Beyrut : Dâru Sadır, 1968), II, 67; Cemalüddin Ebu'l-Ferec Abdurrahman b. Ali İbnü'l-Cevzi, el-Muntazam fi tarihi'l-mülûk ve'l-ümem (Beyrut: Darü'l-Kütübü'l-İlmiyye, 1992), VI, 23.

20 Belâzürî, Ensâbü'l-eşrâf, V, 299.

21 Hakan Temir, Emevîlerde Valilik (Kahramanmaraş: Samer Yayınları, 2019), 6.
} 
Bu noktadan sonra sözü, Muâviye sonrası Emevî halifeleri Yezîd b. Muâviye, Mervân b. Hakem ve Abdülmelik b. Mervân dönemlerinde, Husayn b. Nümeyr' in aktif rol aldığı önemli olaylara getirebiliriz:

\section{A. Kerbelâ Hadisesindeki Rolü}

Kaynaklardaki bilgilerden Husayn b. Nümeyr'in Yezîd döneminde Kûfe'ye gönderildiği ve sahibu'ş-şurta (emniyet müdürü) olarak atandığ1 anlaşılmaktadır. ${ }^{22}$ Onun Kûfe'de bulunduğu dönemde Hz. Hüseyin'in Yezîd'in halife oluşuna itiraz ederek başlattığı siyasî hareket ortaya çıkmış ${ }^{23}$ ve hiç şüphe yok ki Husayn b. Nümeyr sadık bir Emevî komutanı olarak başından beri bu hadiselerde aktif rol almıştır. Onun Kûfe'ye gönderilmiş olması burada meydana gelen toplumsal dalgalanmalarla da alakalı olmalıdır. Zira Ubeydullah'tan önce Kûfe valiliğini yürütmekte olan Numan b. Beşir, buradaki siyasî gelişmelere karşı yumuşak davranmış, Yezîd'in istediği ölçüde sert tedbirler almakta yetersiz kalmıştı. Bu da hadiselerin Emevîler ve Yezîd'in iktidarı için tehlikeli bir boyut kazanmasına yol açmıştı. Bu şartlar altında Ubeydullah b. Ziyâd gibi katı tutumlu ${ }^{24}$ bir vali ile birlikte Husayn b. Nümeyr gibi güvenilir askerlere ihtiyaç duyulmaktayd. Bütün bu ihtimallerden dolayı Husayn'ın Kûfe'ye geliş sebebinin Hz. Hüseyin'in hareketiyle çok yakından alakalı olması gerekir.

$\mathrm{Bu}$ arada Hz. Hüseyin, Kûfeliler'in ssrarlı mektupları üzerine Yezîd b. Muâviye'nin halifeliğini geçersiz sayarak ve ona karşı kıyam etmek maksadıyla Mekke'den Kûfe'ye doğru yola çıktı. Buna karşın Yezîd'in Irak valisi olarak tayin ettiği Ubeydullah b. Ziyâd ile güvenlikten sorumlu olan Husayn b. Nümeyr karşı tedbirler almakta gecikmediler. Öncelikle Kûfe içindeki Hz. Hüseyin taraftarlarını etkisiz hale getirdiler. Ardından Hz. Hüseyin'in elçisi Müslim b. Akil ile ona destek olanlar idam edildi. ${ }^{25}$ Ubeydullah b. Ziyâd, Kûfe'de güvenliğin Emevîler lehine sağlanmasından sonra, Husayn b. Nümeyr komutasında gönderdiği bir orduyla Mekke-Kûfe yolunu kontrol altına aldı. Ayrıca Kûfeliler'in Hicaz'la irtibat kurmasına

\footnotetext{
22 Ebû Hanîfe Ahmed b. Dâvûd b. Venend Dîneverî, el-Ahbârü't-tıvâl (Kahire: Daru İhyai'l-Kütübi'l-Arabî, 1960), 240; Taberî, Tarihü 't-Taberî, V, 394; Belâzürî, Ensâbü'l-eşrâf, III, 166. Kûfe Şurta Teşkilatı'nın yapısı hakkında detaylı bilgi için bkz. Mehmet Mahfuz Söylemez, Bedevîlikten Hadariliğe Kûfe (Ankara: Ankara Okulu Yayınları, 2015), 232.

23 Adem Apak, “Kerbelâ Hadisesi'nin Siyasî Sebebi Yezîd b. Muaviye'nin Veliaht Tayin Edilmesi Meselesi Üzerine Tespit ve Değerlendirmeler”, Çeşitli Yönleriyle Kerbela Uluslararası Kerbela Sempozyumu, Sivas, 2010, ed. Alim Yıldı, Ali Aksu, Asitan Yayıncılık, (Sivas:2010), I, 4.

24 Ahmet Turan Yüksel, "Kerbelâ Vakası'nda Ubeydullah b. Ziyâd'ın Rolü”, Çeşitli Yönleriyle Kerbela Uluslararası Kerbela Sempozyumu, Sivas, 2010, ed. Alim Yıldız, Ali Aksu, Asitan Yayınc1lı, (Sivas:2010), I, 319.

25 İbn Hibban, Muhammed b. Hibban b. Ahmed, es-Siretü'n-nebeviyye ve ahbâru'l-hulefa (Beyrut: 1997), II, 556-557.
} 
engel olmak, Hz. Hüseyin ile haberleşme ağlarını etkisiz hale getirmek gayesiyle Husayn b. Nümeyr'in komutasındaki dört bin kişilik bir süvari birliği Kûfe'nin etrafını sürekli denetliyordu. ${ }^{26}$ Bu esnada Hz. Hüseyin, Kays b. Müshir ile birlikte Kûfeliler'e hitaben bir mektup gönderdiyse de elçi, Husayn b. Nümeyr tarafından yakalanarak Ubeydullah'a gönderildi. Ubeydullah da Kays' 1 vali konağının burçlarından aşağı atmak suretiyle öldürdü. ${ }^{27}$

Husayn b. Nümeyr, bu görevin bir parçası olarak Kûfe halkından olan Temîmli Hurr b. Yezîd'i bin kişilik bir kuvvetin başına getirerek ona Hz. Hüseyin'i karşılamasını ve hareketlerini takip ve kontrol altında tutmasını emretti. Hurr b. Yezîd uzun bir mesafe boyunca bu gözetim görevini yerine getirdi. Nihayet Hz. Hüseyin ve beraberindekileri Kerbelâ denilen yere kadar getirdi. ${ }^{28}$

Ubeydullah b. Ziyâd, Hz. Hüseyin'in Kerbelâ'ya ulaştığını haber alınca Ömer b. Sa'd b. Ebî Vakkas komutasında bir orduyu Kerbelâ'ya sevk etmiştir. ${ }^{29}$ Ömer b. Sa'd, burada Hz. Hüseyin ile Ubeydullah b. Ziyâd arasında cereyan eden bir dizi mektuplaşmaya aracılık etmiştir. Ancak Hz. Hüseyin Ubeydullah'1n öne sürdüğü talepleri kabul etmediği gibi ${ }^{30}$ Yezîd'e biat etmeyeceğini de ifade etti. Bunun üzerine Ubeydullah b. Ziyâd, Husayn b. Nümeyr, Şeb'es b. Rib’î, Şemr b. Zilcevşen gibi komutanların da bulunduğu bir birliği Ömer b. Sa'd'ın daha kararlı hareket etmesi için Kerbelâ'ya göndermiştir. ${ }^{31}$ Husayn b. Nümeyr'in Ömer b. Sa'd'in ordusunda hangi konumda görev aldığ 1 tam olarak bilinmemektedir. Orduya sonradan katıldığına göre öncü birliği ya da să̆ veya sol cenah komutanlarının önceden belirlenmiş olması gerekir. Yukarıda da ifade edildiği gibi ordunun normal düzeni içinde bir görev almamış ancak Ömer b. Sa'd'ın Hüseyin ile savaşmaktan kaçınması ihtimaline binaen Şemr ile birlikte Kerbelâ'ya gönderilmiştir. Savaşta komuta ettiği bir birlik olmasa da Husayn Hz.

\footnotetext{
26 Dîneverî, el-Ahbârü't-tıvâl, 243.

27 Belâzürî, Ensâbü'l-eşrâf, III, 167; Dîneverî, el-Ahbârü't-tıvâl, 246.

28 Ebü'l-Abbâs Takiyyüddîn Ahmed b. Alî Makrîzî, İmtâ 'u'l-esmâ' bimâ li'r-resûl mine'l-ebnâ'i (enbâ'i) ve'l-ahvâl ve'l-hafede ve'l-metâ ' (Beyrut: Dârü'l-Kütübi'l-İlmiyye, 1999), V, 364; Hurr b. Yezîd Hz. Hüseyin'i Kerbelâ'ya kadar getirdikten sonra onun tarafına geçmiştir. Bu konuda geniş bir değerlendirme için bkz. Murat Sarıcık, "Kerbelâ Olayında el-Hurr b. Yezîd ve Hz. Hüseyin'le Mücadelesi”, Süleyman Demirel Üniversitesi İlahiyat Fakültesi Dergisi, 2 (1995): 138.

29 Ömer b. Sa'd Kerbelâ'dan kısa bir önce Ubeydullah b. Ziyad tarafından Rey valiliğine tayin edilmişti. Hz. Hüseyin'in yola çıktığı haber alınınca Ubeydullah Rey valiliği karşılığında Ömer'i bu meseleyle ilgilenmekle görevlendirdi. Ömer b. Sa'd bu görevden affını istediyse de talebi kabul edilmemiştir. Taberî, Tarihü't-Taberî, V, 389.

30 Taberî, Tarihü't-Taberî, V, 414.

31 Dîneverî, el-Ahbârü't-Tıvâl, 254.
} 
Hüseyin'le savaşmakta gösterdiği cüretkarlıkla asıl görevini yerine getirmiştir. Nitekim Kûfeli askerlerin Hz. Hüseyin'e saldırmakta tereddüt ettikleri anlarda ortaya çıkarak Hz. Hüseyin'in etrafındakilere yönelik nihai saldırıyı organize ettiği bilinmektedir. Ömer'in emri üzerine Husayn b. Nümeyr ve beraberindeki askerler Hz. Hüseyin tek başına kalıncaya kadar etrafındakileri öldürdüler. Hz. Hüseyin tek başına kalınca hiçbir kabile onu şehid etme sorumluluğunu üzerine almak istemedi. Bu yüzden Kûfeliler bir süre ona saldırmadan öylece beklediler. Bu esnada çok susamış olan $\mathrm{Hz}$. Hüseyin bir bardak su istedi. Suyu içmek için ağzına götürdüğü sırada Husayn b. Nümeyr attığı bir okla onu ağzından vurdu ve Hz. Hüseyin'in elindeki bardak yere düştü. ${ }^{32}$ Husayn'ın bu hamlesi neticesi çoktan belli olmuş olan savaşın asıl hedefini de gerçekleştirmiş oluyordu. Husayn'ın darbesinden sonra ordudaki diğer askerler Hz. Hüseyin'e saldırıp şehid edene kadar kılıçlarıyla ona vurdular. Böylece hiç kimsenin cüret edemediği bir şeye Husayn b. Nümeyr cüret etmiş oluyordu. Bu cüretkârlı̆̆ı onun Emevî Devleti'ne olan sadakatini göstermiş ve bu uğurda en aşırı noktalara kadar gidebileceğine de işaret etmiş oluyordu.

Emevî ordusu Kerbelâ'da bir gün kaldıktan sonra oradan ayrıldı. Şehid edilenlerin kesik başları ordu komutanlarına dağıtılmıştı. Husayn b. Nümeyr'e de on yedi kesik baş zimmet edildi. ${ }^{33}$

\section{B. Harre Savaşı ve Husayn b. Nümeyr}

Kerbelâ vakasından sonra ve Kûfe'de kontrolün kesin bir biçimde Emevî idaresine geçmesinin ardından Husayn b. Nümeyr tekrar Şam’a döndü. Ancak Kerbelâ vakası İslam dünyasında bir infiale yol açmış ve toplumun farklı kesimlerinden insanlar Yezîd iktidarına karşı ayaklanma hazırlıklarına girişmişlerdir. Bunlardan bir tanesi de Medinelilerin Abdullah b. Hanzale öncülüğünde başlatmış olduğu harekettir. ${ }^{34}$ Yezîd yönetiminden

32 Dîneverî, el-Ahbârü 't-tıvâl, 258. el-Ahbârü't-tıvâl'da Husayn b. Nümeyr olarak yazılan isim benzer anlatımla birkaç yerde Husayn b. Temîm olarak kaydedilmiştir. Aynı şekilde Kûfe'nin etrafına nöbetçi birliği göndermesi istenen isim de bazı kaynaklarda Husayn b. Nümeyr bazen de Husayn b. Temîm olarak kaydedilmiştir. Her iki ismin de aynı kişiye yani İbn Nümeyr'e ait olduğu kanaatindeyiz. Bkz. Taberî, Tarihü't-Taberî, V, 449; İbn Miskeveyh, Tecâribu'l-ümem, II, 79; Cemalüddin Ebu'l-Ferec Abdurrahman b. Ali İbnü'l-Cevzi, el-Muntazam fi tarihi 'l-mülûk ve'l-ümem (Beyrut: Darü'l-Kütübi'l-İlmiyye, 1992), V, 340.

33 Dîneverî, el-Ahbârü 't-tıvâl, 259. Baş kesmenin sembolik yönleri ve İslam tarihindeki diğer örnekleri için bkz. Mehmet Akbaş, "Ölü Bedenlere Kasdetme Girişimi Olarak İslam Tarihinde İlk Baş Kesme Hadisesinin Ortaya Çıkışı ve Emevîler Döneminde Başları Kesilenler”, Harran Üniversitesi Illahiyat Fakültesi Dergisi, 21/36 (2016): 112-127.

34 Harre vakasının yalnızca bu nedenle başladığını söylemek yanlış olur. Bu konudaki bazı değerlendirmeler için bkz. Ünal Kılıç, "Harre Vakasının Sebepleri Hakkında Bazı Mülahazalar", Cumhuriyet Üniversitesi Illahiyat Fakültesi Dergisi, 4 (2000): 318 vd. 
hoşnut olmayan Medineliler, Vali Osman b. Muhammed b. Ebî Süfyân'ı ve Ümeyyeoğullarını Medine'den çıkardı. ${ }^{35}$ Medine'de bir isyan hazırlığının olduğunu ve Mekke'de Abdullah b. Zübeyr'in halife olarak biat aldığını öğrenen Yezîd, Müslim b. Ukbe komutasında hazırlanan ve Şam'ın seçkin askerlerinden oluşturulan bir orduyu Medine'deki isyanı bastırmak, akabinde de Mekke' de hilafetini ilan etmiş olan Abdullah b. Zübeyr üzerine yürümekle görevlendirdi. Humus'taki Kindeliler'in komutanı olarak 36 orduya dâhil edilen ve Emevîler'e bağlılı̆̆ını daha önce defalarca ispatlamış olan Husayn b. Nümeyr de ordunun ikinci komutanı olarak tayin edildi ve Müslim b. Ukbe'ye bir şey olması halinde birinci komutanlığa getirilmesi bizzat Yezîd tarafından Müslim'e emredildi. ${ }^{37}$

Müslim komutasındaki ordu Medine'nin doğusunda Harre denilen mevkide Abdullah b. Hanzale'nin ordusuyla karşılaştı. Ordular birbirine yaklaşınca Müslim, Husayn b. Nümeyr'e emrindeki askerlerle ilerlemesini emretti. O da Abdullah b. Hanzale'nin ordusuna yakın bir yere kadar ilerledi. Sonra da Şam ordusunun okçuları oraya geldiler. ${ }^{38}$ Karşılıklı konuşmalardan sonra meydana gelen şiddetli savaşta Medineliler mağlup oldular. Husayn b. Nümeyr, savaştan sonra Medinelilere aşırı derecede tahkir edici davranan ve onlardan pek çok kişiyi idam eden, bu nedenle de "Müsrif" olarak lakaplandırılan Müslim b. Ukbe'ye karşı bazı Medinelileri himaye etmiştir. Bunlardan biri de Ali b. Abdullah b. Abbas'tır. Müslim Medinelilerden, Yezîd'e onun ömür boyu köleleri olmak üzere (عبد قن) biat etmelerini talep etti. Bu şekilde biat etmeyi reddeden Muhammed b. Ebû Cehm'in boynu hemen oracıkta vurulunca geri kalan Medineliler Müslim'in istediği şekilde biat ettiler. Ancak Ali b. Abdullah b. Abbas Yezîd'e bu şekilde biat etmek istememiş ve Husayn'a sı̆̆ınmış o da onu himaye etmeyi kabul etmiştir. Ali'nin annesinin Kindeli bir kadın olması Husayn'ın onu himayesinde etkili olmuş ve Ali bu sayede canını kurtarabilmiştir. Müslim'in elçisi onu öldürmek üzere geldiyse de Husayn onu geri çevirmiştir. Bunun üzerine Müslim, "İtaatsizlik mi ediyorsun ey Husayn?” diye sorunca Husayn: "Bu konuda evet! Vallahi kız kardeşimizin oğlu sana o şekilde biat etmeyecek!” dedi. Sayıları dört bini bulan Kinde'ye mensup Humuslular da her şartta Emevîler'e destek vermelerine rağmen bu olayda

\footnotetext{
Ebû Bekir Muhammed b. Halef Vekî', Ahbâru'l-kudat (Mısır: el-Mektebetü't-Ticariyyeti'l-Kübra, 1947), I, 123.

Belâzürî, Ensâbü'l-eşrâf, V, 326; Dîneverî, Ahbârü't-tıvâl, 264.

7 Hayyat, Tarihu Halife b. Hayyat, I, 238; Belâzürî, Ensâbü'l-eşrâf, V, 322; Taberî, Tarihü 't-Taberî, V, 484.

38 Taberî, Tarihü 't-Taberî, V, 490.

39 Önceden anne-babası da köle olan, hürriyete kavuşma emeli de olmayan köle. Bkz. Ebû Mansur Abdülmelik b. Muhammed b. İsmail Seâlibî, Fikhu'l-luga ve sirrü'l-arabiyye (Beyrut: İhyâu Turasi'l-Arabi, 2002), 54.
} 
asabiyetten dolayı Husayn'ın arkasında durmuşlar ve işlerin kontrolden çıkmasından endişe eden Müslim herhangi bir şey yapamamıştır. ${ }^{40}$ Ayrıca buradaki emre itaatsizlik Emevî Devleti'ne karşı bir tavir olmayıp doğrudan Müslim b. Ukbe'ye yöneliktir. Akabinde Husayn, Ali'yi Müslim'e götürmüş o da Yezîd'e itaat etmek üzere biat etmiştir. ${ }^{41}$ Ali b. Abdullah, bu olay üzerine okuduğu şiirde Kinde kabilesinden olan dayılarının eskiden beri krallar olduğunu ve kendisini "Müsrif"'e karşı koruduklarını dile getirmiştir. ${ }^{42}$

\section{Abdullah b. Zübeyr İsyanı ve Mekke'nin Kuşatılması}

Müslim b. Ukbe Medine'deki görevini yerine getirdikten sonra Mekke'de halifeliğini ilan etmiş olan Abdullah b. Zübeyr üzerine yürüdü. Ancak Mekke yolu üzerindeki Ebva köyünde rahatsızlandı. Zaten yaşlı olan Müslim, rahatsızlığının artması üzerine öleceğini anlayınca ordu komutanlarını topladı ve Yezîd'in emri gereğince Husayn b. Nümeyr'i onlara komutan atadığını bildirdi. Görev teslimi esnasında yaptığ1 konuşmada Husayn b. Nümeyr'den hoşlanmadığını açıkça ifade etmiş ve bu atamayı Yezîd'in emrine muhalefet etmemek için yerine getirdiğini belirtmiştir. ${ }^{43}$ Rivayete göre Müslim, hastalığı ağırlaşıp öleceğini anlayınca Husayn' 1 çă̆ırdı ve ona hakaretamiz ifadelerle "Ey eşek semerinin oğlu! ${ }^{44}$ Eğer bana verilen bir emir olmasaydı seni bu orduya komutan tayin etmezdim. Ancak emîru'l-müminin seni benden sonraki komutan tayin etti ben onun emrini çiğnemek istemiyorum. ${ }^{45}$ Yine de şu anda seni orduya komutan yapmak için mi yoksa boynunu vurmak için mi çağırdı̆̆ımı bilmiyorsun" dedi. Husayn "Allah sana iyilik versin. Ben senin emrindeki bir okum. Beni dilediğin tarafa fırlatabilirsin" dedi. ${ }^{46}$ Bunun üzerine Müslim komutayı ona devrettiğini belirterek Mekke ve Kureyşliler'e nasıl davranacağına dair bazı nasihatlerde bulundu. ${ }^{47}$ Sonra da ordunun ileri gelenlerini çağırarak Yezîd'in kendisinden sonra komutayı Husayn'a bırakmasını emrettiğini ve ölümü anında bu emre itaatsizlik etmek

\footnotetext{
Ebu Cafer el-Bağdadî, el-Münemmak fi ahbari Kureyş, 316; Meçhul, Ahbâru devleti'l-Abbasiyye, thk. Abdulaziz edDurî, Abdülcebbar Muttalibi (Beyrut: Daru't-Talî'a, tsz.), 136.

41 Belâzürî, Ensâbü̈'l-eşrâf, V, 330; IV, 79.

42 Belâzürî, Ensâbü'l-eşrâf, V, 330 .

43 Taberî, Tarihü't-Taberî, V, 496.

44 Taberî, Tarihü't-Taberî, V, 496.

45 İbnü'l-Cevzi, el-Muntazam fi tarihi 'l-mülûk ve'l-ümem VI, 21.

46 Belâzürî, Ensâbü'l-eşrâf, V, 336.

47 Hayyat, Tarihu Halife b. Hayyat, I, 255; Belâzürî, Ensâbü'l-eşrâf, V, 336.
} 
istemediğini belirtti. Onlardan Husayn'a itaat etmelerini istedi. ${ }^{48}$ Müslim'in bu sözlerinden onun Husayn' dan hoşlanmadığı anlaşılmaktadır. İslam tarihi kaynaklarında Müslim ile Husayn arasındaki problemin nedeni ifade edilmemektedir. Ancak her ikisinin da Şam yönetiminin içinde yer alan figürler olması hasebiyle başkentteki çıkarlarının çatışması muhtemeldir. Bu nedenle aralarında bir soğukluğun olduğu varsayılabilir. Bununla birlikte Husayn'ın Kinde'nin büyüklerinden biri ve Humus karargâhı komutanı olarak Yezîd'in yanında önemli bir değeri vardı ve Müslim bunu göz ardı edemezdi.

Ağır hasta olan Müslim b. Ukbe bu görevlendirmeyi yaptıktan kısa bir süre sonra Ebvâ'da vefat etti. Husayn b. Nümeyr, komutasına geçen ordu ile Abdullah b. Zübeyr üzerine harekete devam etti. Müslim ise Mekke ile Medine arasında bulunan Müşellel mevkiinde defnedildi. ${ }^{49}$

Husayn b. Nümeyr komutasındaki Şam askerlerinden oluşan ordu 64/683 yılında Mekke'ye ulaştı. Şehrin hemen dışında karargâhını kuran Husayn, Mekke'yi dört bir taraftan kuşattı. ${ }^{50}$ Buna karşılık Abdullah b. Zübeyr şehrin içinde kalarak bir meydan savaşından ya da huruç hareketinden kaçındı. Bir ara Abdullah b. Zübeyr Husayn'ı mübarezeye davet ettiyse de Husayn'a bunu kabul ettiremedi. ${ }^{51}$ Yaklaşık iki ay devam eden kuşatma sırasında Husayn b. Nümeyr'in Kâbe'ye hâkim bir konumdaki Ebû Kubeys ve Kuaykıan tepelerin ${ }^{52}$ kurdurduğu mancınıklarla Abdullah b. Zübeyr'in sığındığı Harem-i Şerif ve Kâbe taş yağmuruna tutuldu. Ateşle tutuşturulan yağlı paçavralarla Kâbe de vurulmuş bu yüzden Kâbe'nin örtüsü ve ahşap kısımları yanmıştır. ${ }^{53}$ Kâbe yangından öyle zarar gördü ki "bir kuş üzerine konacak olsa taşları dökülüyordu." ${ }^{54} \mathrm{Bu}$ şartlar altında günlerce Kâbe'yi kimse tavaf edememiştir. ${ }^{55}$ Bir süre sonra Ebû Kubeys tepesindeki mancınığa yıldırım çarpması sonucunda mancınık zarar gördü ve askerler o mancınığı bir daha kullanamadılar. ${ }^{56}$

48 Belâzürî, Ensâbü'l-eşrâf, V, 338; Taberî, Tarihü't-Taberî, V, 496-497.

9 Belâzürî, Ensâbü'l-eşrâf, V, 334 .

50 Ebû Abdullah Muhammed b. Sa'd b. Meni' ez-Zührî İbn Sa'd, el-Cüz'ü'l-mütemmim li 't-tabakâti İbn Sa'd (Taif: Mektebetü's-Sadik, 1993), II, 67.

51 Ebû Abdillâh Muhammed b. Abdillâh b. Muhammed el-Hâkim Nîsâbûrî, el-Müstedrek (Beyrut: Daru'l-Kütübü'lİlmiyye, 1990), III, 634.

52 Muhammed b. Ahmed b. Temîm el-Mağribî Ebü'l-Arab, el-Mihan (Riyad: Daru'l-Ulum, 1984), 283.

53 Kâbe'nin Husayn'ın mancınıklarından değil de başka bazı sebeplerden dolayı yandığına dair rivayetler için bkz. Ebü'l-Fida İmadüddin İsmail b. Ömer İbn Kesir, el-Bidâye ve'n-nihaye (Daru'l-Fikr, 1986), VIII, 225.

54 el-Ezrakî, Ahbâru Mekke, I, 199.

55 Ebü'l-Arab, el-Mihan, 203.

56 Belâzürî, Ensâbü'l-eşrâf, V, 341. 
Mekke'nin etrafındaki kuşatma ve çarpışmalar Yezîd'in ölüm haberi Mekke'ye ulaşıncaya kadar (1 Rebîülâhir 64/27 Kasım 683) devam etti. ${ }^{57}$ Yezîd'in ölüm haberi gelince Abdullah b. Zübeyr onların savaşmaya devam etmesinin anlamsız olduğunu söylediyse de Husayn Yezîd'in ölüm haberini kendi kaynaklarına doğrulatmak için bekledi. Bir yandan da Yezîd'in yerine gelecek olan halife adına savaştığını söyleyerek ${ }^{58}$ çarpışmaya devam etti ve Kâbe'ye sığınmış olan Abdullah b. Zübeyr ve ordusu üzerine mancınıklarla yanan taşlar attı. Yağlı bezlerle sarılmış bu taşlardan Kâbe'nin örtüsü yanınca Abdullah b. Zübeyr, Mekke eşrafından oluşan bir heyeti Husayn'a gönderip Kâbe'nin yandı̆̆ını haber verdi. Ayrıca Yezîd'in ölümünden sonra herhangi bir kimsenin hilafeti üzerinde de uzlaşılamadığını bildirdi. Bunun üzerine Husayn böyle bir durumda Şam'dan gelecek haberin çok gecikmeyeceğini ifade etti ve çarpışmalara ara verdi. Husayn'ın güvendiği kimselerden biri olan ve aralarında akrabalık bağı da olan Sabit b. Kays gelip Husayn'a Yezîd'in öldüğünü ve durumun İbn Zübeyr'in söylediği gibi olduğunu haber verinceye kadar da kuşatma devam etti. ${ }^{59}$ Husayn' in Mekke kuşatması toplam elli gün sürdü. ${ }^{60}$ Kâbe'nin yanmasından on bir gün sonra Yezîd ölmüştü. ${ }^{61}$ Fakat Husayn'ın çabuk ikna olmaması kuşatmanın bir süre daha devam etmesine yol açtı.

Savaş durdurulunca iki taraf arasında heyetler bazında görüşmeler cereyan etti. Abdullah b. Zübeyr'in gönderdiği heyet Husayn'1 Suriye'ye dönmeye ikna etti. Husayn b. Nümeyr ordusunu çekmeden önce Kâbe'yi tavaf etmek istediğini bildiren bir elçiyi Abdullah b. Zübeyr'e gönderdi. ${ }^{62}$ Abdullah b. Zübeyr arkadaşlarıyla yaptı̆̆ı istişare sonucunda bu isteği yerinde buldu ve Husayn b. Nümeyr tavaf için Mekke'ye indi. Burada Abdullah b. Zübeyr ile aralarında bir görüşme gerçekleşti. Bu görüşmede Husayn ile Abdullah arasında şöyle bir diyalog cereyan etti. Abdullah b. Zübeyr Husayn'a "Yezîd öldü. Bu [hilafet] işine en layık olan insan benim. ${ }^{63}$ Çünkü Osman, bu konuda bana bir ahit vermişti. Talha ve Zübeyr arkamda namaz kıldılar. Osman'ın bu ahdini [muhasara altında olduğu günlerde] müminlerin annesi Aişe'ye bildirdim. Bütün bu sebeplerden dolayı bana biat

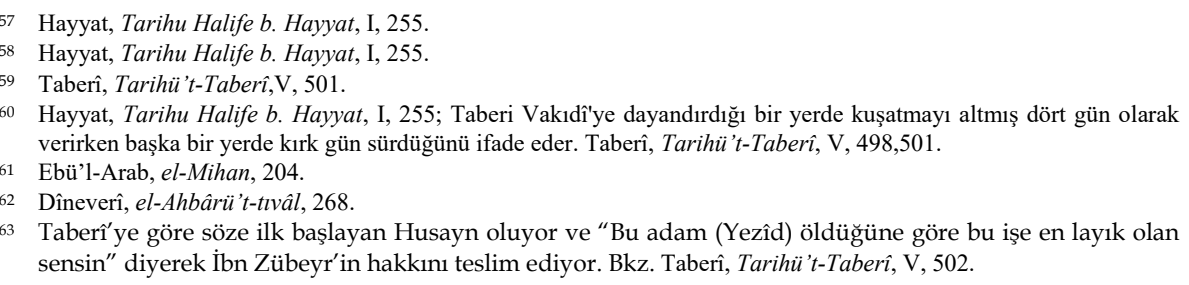

63 Taberî́ye göre söze ilk başlayan Husayn oluyor ve "Bu adam (Yezîd) öldüğüne göre bu işe en layık olan sensin" diyerek İbn Zübeyr' in hakkını teslim ediyor. Bkz. Taberî, Tarihü 't-Taberî, V, 502. 
et! İnsanların benimle beraber girdikleri daireye sen de gir! Böylece onların lehine olan şey, senin de lehine olur; onların aleyhine olan şey, senin de aleyhine olur" dedi Husayn b. Nümeyr ona cevaben: "Ey Ebû Bekir! Vallahi kalbimde olanın dışında bir şeyle [ikiyüzlü davranarak] sana yaklaşmam. Şam'a giderim. Şayet onların senin etrafında toplandıklarını görürsem sana itaat ederim ve sana isyan edenlerle savaşırım. Yok eğer onların senden başkası etrafında toplandıklarını görürsem ben de o kişiye itaat eder ve seninle savaşırım. Ancak sana şu teklifte de bulunuyorum. Benimle beraber Şam'a gel, seni Arapların hâkimi yapayım! Şu benimle birlikte olan ordu, Şamlıların ileri gelenleri ve süvarileridir. Allah'a yemin ederim ki onlardan iki kişi bile sana biatten geri kalmaz" dedi. Bu teklife Abdullah, "Bir elçi göndersem olmaz mı?" diye karş1lı verince Husayn, "Senin elçin senin yerini tutmaz" diyerek teklifini reddetti. ${ }^{64}$ Abdullah da onun teklifini kabul etmedi ve Husayn Kâbe' yi tavaf ederek Şam'a geri döndü. ${ }^{65}$

Bazı rivayetlere göre Abdullah b. Zübeyr, Husayn Mekke'den ayrıldıktan sonra onun teklifini kabul etmediği için pişman olmuş ve haber göndererek "Bana burada biat edin ki ben de size güvenerek sizinle Şam'a geleyim" demişse de Husayn yoluna devam ederek onun teklifini kabul etmemiştir. ${ }^{66}$ Büyük bir ihtimalle Abdullah b. Zübeyr de Hz. Hüseyin'in akıbetinden kendisi için dersler çıarmış ve biat almadan Şamlılara güvenmek istememişti.

Abdullah b. Zübeyr Husayn'ın ayrılmasından sonra Kâbe'yi temellerine kadar yıkmış ve yeniden inşa etmiştir. Bu esnada Hicr'i Kâbe'ye dâhil etmek ve Kâbe'ye iki kapı açmak gibi bazı tasarruflarda bulunmuştur. ${ }^{67}$

Husayn'ın Kâbe'yi tavaf etmek için Mekke'ye indiği esnada Abdullah b. Zübeyr ile Husayn arasında ilginç bir diyaloğun gerçekleştiğine dair bir rivayet İslam tarihi kaynaklarında şöyle yer almaktadır. Harem bölgesine atıyla giren Husayn b. Nümeyr'in atını zapt etmek için çabaladığını gören Abdullah ona neden böyle davrandığını sordu. Bunun üzerine Husayn "Atımın Harem güvercinlerini öldürmesinden endişe ediyorum" dedi, İbn Zübeyr "bu seni sıkıntıya sokuyor ama Müslümanları öldürmek seni

\footnotetext{
64 İbn Sa‘d, et-Tabakâtü'l-kübrâ, II, 67; İbnü'l-Cevzi, el-Muntazam fi tarihi'l-mülûkve'l-ümem, VI, 23.

65 Dineverî́de geçen ilave bir bilgiye göre Husayn b. Nümeyr Abdullah b. Zübeyr'i daha politik davranmadığı için eleştirmiş ve onun başarılı bir siyasetçi olacağından ümidini keserek Şam’a dönmüştür. Dîneverî, el-Ahbârü't-tıvâl, 268; Taberî, Tarihü 't-Taberî, V, 502; İbn Miskeveyh, Tecâribu'l-ümem, II, 92.

66 Taberî, Tarihü't-Taberî, V, 502.

67 Ahmed b. Yahyâ b. Câbir b. Dâvûd Belâzürî, Fütûhu'l-büldân (Beyrut: Daru'l-Mektebeti'l-Hilal, 1988), 55.
} 
rahatsız etmiyor öyle mi?" dedi. ${ }^{68}$ Taberî́nin, senedini zikretmediği için ravilerinin kim olduğunu öğrenemediğimiz bu rivayetinin Husayn'ın yaptığ1 kötülükleri vurgulamak için uydurulmuş olması muhtemeldir. Öte yandan Husayn b. Nümeyr, Emevî Devleti'ne ve kabilesine olan bağlllı̆̆ nedeniyle, kim olursa olsun bu ikisinin düşmanlarını kendi düşmanı bellemek suretiyle yaptıklarına meşruiyet kazandırıyor da olabilir. Dolayısıyla, rivayeti doğru kabul edersek bir güvercini incitmekten çekinen bir Emevî komutanının zihnî arka planında Emevî Devleti'ne isyan edenlerin suçluluğuna dair en ufak bir tereddüdü olmadığı anlaşılmaktadır.

\section{Mervân b. Hakem'in Halife Seçilmesindeki Rolü}

Abdullah b. Zübeyr'in Mekke'de muhasara edilmesi esnasında Yezîd b. Muâviye ölünce Husayn kuşatmayı sona erdirip Dımaşk'a dönmüştü. Yezîd'in yerine kendisine biat edilen Muâviye b. Yezîd de kısa bir süre sonra vefat edince Emevî hanedanı içinde kimin halife olması gerektiği konusunda anlaşmazlıklar çıtı. Neredeyse hanedanın siyasî hayatı sona ermekle karşı karşıya kaldı. Ürdün'deki Taberiyye şehri hariç olmak üzere her yer Abdullah b. Zübeyr'e biat etmişti. Hatta Emevîler'in en güçlü oldukları Suriye bölgesi bile genel olarak Abdullah b. Zübeyr'in hilafetini kabul etmek eğilimindeydi. ${ }^{69}$ Şam'daki Abdullah b. Zübeyr taraftarları "Abdullah b. Zübeyr zamanının en iyi insanıdır. Hz. Peygamber'in havarisinin oğludur. Hz. Osman'ın kanını dava etmiştir. Cesaretli, faziletli ve yaşı uygun bir kimsedir" diyerek İbn Zübeyr'e biat için propaganda yapıyorlard1. ${ }^{70}$ Hatta Husayn b. Nümeyr'in Mekke'den getirdiği haberlerden etkilenen Mervân b. Hakem'in bile yol hazırlıkları yapıp Abdullah b. Zübeyr'e biat etmeye hazırlandığı ancak Ubeydullah'ın onu kınayarak hilafet makamına oturmaya razı ettiği nakledilmektedir. ${ }^{71}$

$\mathrm{Bu}$ şartlar altında Dımaşk yakınlarındaki Câbiye'de toplanan Ümeyyeoğullarının ileri gelenleri ve aralarında Husayn b. Nümeyr'in de bulunduğu Emevî Devleti yöneticileri kimin halife olacağını tartışıorlardı. Bazı kimselerin Yezîd b. Muâviye'nin küçük yaştaki oğlu Hâlid b. Yezîd'in halife seçilmesini teklif etmesine karşılık Husayn b. Nümeyr, Yezîd nezdindeki konumuna rağmen oğlunun yaşının küçüklüğünü öne sürerek

\footnotetext{
Taberî, Tarihü't-Taberî, V, 502.

Belâzürî, Ensâbü'l-eşrâf, VI, 295.

Belâzürî, Ensâbü'l-eşrâf, VI, 259.

71 Taberî, Tarihü't-Taberî, V, 530.
} 
Mervân'dan yana görüş belirtti. ${ }^{72}$ Husayn b. Nümeyr'in bu kararı verirken öne sürdüğü Hâlid'in yaşı argümanının tek başına ana sebep olmadığ1 kanaatindeyiz. Muhtemelen Irak valisi Ubeydullah b. Ziyâd ile Yezîd döneminden beri yakın bir şekilde çalışıyor olması da bu görüşünde etkili olmuştur. Zira Mervân'ın hilafetinin en büyük destekçilerinden biri, bazı kaynaklara göre de fikir babası Ubeydullah b. Ziyâd'dır.73

Husayn b. Nümeyr ve diğer destekçilerin çabalarıyla Mervân b. Hakem halife seçildi. Husayn, bu biat sırasında Mervân b. Hakem'den Şam'da bulunan Kinde Kabilesi mensuplarının Belka'ya yerleştirilmesini talep etmiş ve talebi kabul edilmiştir. Bu sayede Husayn, Kinde kabilesine geniş bir arazinin tahsis edilmesini sağlamış ve halife değişikliğini kabilesi lehine bir pazarlık unsuru haline getirmiştir. ${ }^{74}$ Mervân b. Hakem'in halife seçilmesi üzerine Dahhak $b$. Kays liderliğinde ayaklanan Abdullah b. Zübeyr taraftarları ile Mervân b. Hakem arasında meydana gelen Mercirâhıt Savaşı'nda Emevî ordusunun sağ kanadı Husayn b. Nümeyr'e emanet edilmiştir. ${ }^{75}$

\section{Tevvabîn Hareketi ve Husayn b. Nümeyr}

Kerbelâ hadisesi, daha sonra Emevî tarihi boyunca pek çok isyanın tetikleyicisi ve gerekçesi olmuştur. Bunlardan biri de Kûfe'de ortaya çıkan Tevvabîn hareketidir. Bunlar Hz. Hüseyin'i Kûfe'ye davet etmelerine rağmen onu Kerbelâ'da yardımsız bıraktıklarından dolayı çok büyük bir pişmanlık duyan ve adeta kendilerini bu günahtan temizlemek için ölüm pahasına Emevî Devleti'ne karşı kıyam eden bir gruptu. Hareketin lideri, Hz. Peygamber'i hayattayken gören kimselerden olup, hilafeti zamanında Hz. Ali'nin de yakın çevresinde bulunmuş ve onunla birlikte Sıffîn'de çarpışmış olan Süleyman b. Surâd idi. Ne var ki, Süleyman, Hz. Hüseyin Kûfe'ye geldiğinde ona ne katılmış, ne de destek olmuştu. ${ }^{76}$

Süleyman ve beraberindekiler işlemiş oldukları bu günahı ancak Ubeydullah b. Ziyâd, Husayn b. Nümeyr, Şemr b. Zilcevşen ve Ömer b. Sa 'd gibi Kerbelâ hadisesinin faillerini cezalandırmak ya da bu uğurda ölmekle affettirebileceklerini düşünüyorlardı.

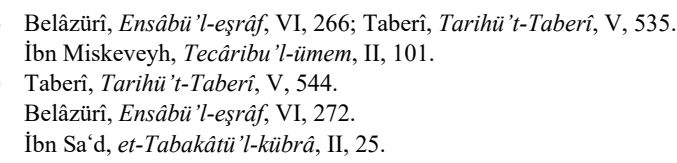


Tevvâbîn hareketindekiler, amaçlarını gerçekleştirmek üzere Süleyman b. Surâd'in evinde gizlice toplanmaya başladılar. 61/680 yılına gelindiğinde halkı gizlice Hz. Hüseyin'in intikamını almak amacıyla örgütlemeye başladılar. Ancak bu hareketin başlatılmasında Hz. Hüseyin'in intikamını alma isteği kadar, Iraklıların Emevîler'e olan düşmanlıkları da etkiliydi. ${ }^{77}$ Silahlı mücadele için propaganda ve destek toplama çalışmaları Yezîd b. Muâviye'nin ölümüne kadar (64/683) sürdürüldü. Yezîd'in ölümünü fırsat bilen bazı hareket mensupları derhal Hz. Hüseyin'in intikamını almayı teklif ettiyse de Süleyman b. Surâd, katillerin Kûfe'de olduklarını ve bunların cezalandırılması halinde Abdullah b. Zübeyr'e katılma ihtimallerinin bulunduğunu söyleyerek daha elverişli şartları kollamayı tercih etti. ${ }^{78}$

Süleyman b. Surâd, Medâin ve Basra gibi şehirlerden yardım sözü alınca harekete geçti. Abdullah b. Zübeyr'in Kûfe valisi ise onları Irak üzerine hareket eden Ubeydullah b. Ziyâd'a karşı birlik olmaya çağırdı. Ancak Süleyman ve beraberindekiler bunu reddedip doğrudan Ubeydullah ile savaşmak üzere Şam istikametine doğru harekete geçtiler. Ne var ki Süleyman'a söz veren 16.000 kişiden sadece 4.000'i orduya katıldı. Bunların da bir kısmı daha sonra ordudan ayrıldı. Aynı esnada Mervân b. Hakem de Mercirâhıt Savaşı'ndan zaferle ayrılmış ve Misır, Ürdün, Filistin gibi bölgeleri hakimiyet altına almıştı. Cezire ve Irak üzerine de Ubeydullah $b$. Ziyâd ve Husayn b. Nümeyr komutasında ordular sevk etmişti. ${ }^{79}$

Süleyman b. Surâd'ın ilk etapta, Ubeydullah'ın Şurahbil b. Zü'1-Kela' komutasındaki öncü birliklerinin üzerine gönderdiği birlik onları mağlup etmeyi başard1. Bunun üzerine Ubeydullah b. Ziyâd, Husayn b. Nümeyr kumandasında 12.000 askerden oluşan bir takviye kuvveti gönderdi. ${ }^{80}$ İki taraf Aynü'l-Verde ${ }^{81}$ denilen yerde karşı karşıya geldiler. Husayn önce onları halifeye itaate davet etti. Buna karşılık Süleyman b. Surâd ise Hz. Hüseyin'in katili olarak kabul ettikleri Ubeydullah b. Ziyâd'ın kendilerine teslim edilmesini, Abdülmelik'in azledilerek hilafetin Ehl-i beyt'e verilmesini talep etti. ${ }^{82}$ Elbette birbirine bu kadar aykırı isteklerin kabul

\footnotetext{
Adem Apak, “Emevîlerin Irak Siyaseti”, Uludağ Üniversitesi İlahiyat Fakültesi Dergisi 18/1 (2009): 112.

Belâzürî, Ensâbü'l-eşrâf, VI, 366.

Belâzürî, VI, 363.

Bo Belâzürî, Ensâbü'l-eşrâf, VI, 370 .

81 Bugün Şanlıurfa'nın Ceylanpınar ilçe merkezi olan Aynü'l-Verde (عين الوردة) (Re'sül'ayn (رأس العين)), Hz. Ömer devrinde Ömer b. Sa'd tarafından fethedilmiştir. (18/639 veya 19/640). Abdülkerim Özaydın, “Aynülverde Savaşı", Türkiye Diyanet Vakfi İslam Ansiklopedisi, (İstanbul: Türkiye Diyanet Vakfı, 1991), IV, 283.

82 Belâzürî, Ensâbü̈'l-eşrâf, VI, 371; Taberî, Tarihü 't-Taberî, V, 598.
} 
edilmesi mümkün değildi. Süleyman b. Surâd'ın bu istekleri sadece sembolik anlamlar taşıyordu. Zira böylece hem Hz. Hüseyin'in şehadetiyle gönlü yaralı olan Ehl-i beyt'e mesaj gönderiyor, hem de Kerbelâ vakasının intikamı için yola çıktıklarını kararlı bir şekilde ifade etmiş oluyordu ${ }^{83} \mathrm{Bu}$ anlamda Tevvabîn hareketi ilginç bir şekilde Hz. Osman'ın kanını talep edenlerle yöntem ve süreç açısından benzerlik arzediyordu. ${ }^{84}$ Nihayet taraflar arasında herhangi bir anlaşma sağlanamayınca 22 Cemâziyelevvel 65/4 Ocak 685 tarihinde şiddetli bir savaş başladı. İlk gün Husayn b. Nümeyr' in askerleri akşama kadar savaştılarsa da bozguna uğradılar. Ertesi gün Ubeydullah b. Ziyâd, Şurahbil b. Zü'-Kila' komutasında 8.000 askeri Husayn'a yardım için gönderince, savaşa bir denge geldi. Ancak yine de Süleyman b. Surâd ve beraberindekiler direndiler. Ancak üçüncü gün Edhem b. Muhriz komutasında 10.000 askerden oluşan yeni bir Emevî gücü gelince Süleyman ve taraftarları için galibiyet artık neredeyse imkânsız hale geldi. ${ }^{85}$ Buna rağmen direnmeye devam eden Süleyman ve askerleri pes etmediler. Bunun üzerine Husayn b. Nümeyr okçularını Tevvabîn mensuplarına ok yağdırmaları için öne çıkardı. ${ }^{86}$ Doksan üç yaşındaki Süleyman b. Surâd da Husayn b. Nümeyr'in oğlu Yezîd tarafından atılan bir okla öldürüldü. ${ }^{87}$ Ondan sonra sancağ1 sırayla devralan Müseyyeb $b$. Necebe, Abdullah b. Sa'd ve Abdullah b. Vâl gibi Tevvabîn ileri gelenleri de hayatlarını kaybettiler. Geri kalan askerler güneşin batmasından faydalanarak Habur'u geçip canlarını kurtardı. ${ }^{88}$

Bir rivayete göre Husayn b. Nümeyr savaş başlamadan önce Süleyman b. Surâd'a "Senin hakkını, akrabalık bağını ve yaşını önemsiyor ve bu yüzden seninle savaşmak istemiyorum" diye haber gönderince Süleyman ona "Allah'a yemin ederim ki, ben hayatı sevdiğim için savaşa çıkmadım" cevabını vermişti. ${ }^{89}$ Nihayet kesilen başları Mervân b. Hakem'e ulaştırılmak üzere Şam'a gönderildi. ${ }^{90}$ Ancak Mervân'ın bu haberi alıp almadı̆̆ı meçhuldür zira aynı zaman aralığında o da hayatını kaybetmiştir.

\footnotetext{
83 Mehmet Mahfuz Söylemez, Kûfe'nin Siyasî Tarihi (Ankara: Ankara Okulu Yayınları, 2015), 173.

84 Şaban Öz, "İktidar Aracı Olarak Kan Talebi Olgusunun Hz. Osman-Hz. Hüseyin Perspektifinde Karşılaştırmalı Bir Analizi”, Çeşitti Yönleriyle Kerbela Uluslararası Kerbela Sempozyumu, Sivas, 2010, ed. Alim Yıldız, Ali Aksu, Asitan Yayıncılik, (Sivas:2010), I, 292.

85 Belâzürî, Ensâbü'l-eşrâf, VI, 371.

86 İbn Miskeveyh, Tecâribu'l-ümem, II, 126.

87 İbnü'l-Cevzi, el-Muntazam fi tarihi'l-mülûk ve'l-ümem, VI, 47; Taberî, Tarihü 't-Taberî, XI, 523.

88 Belâzürî, Ensâbü'l-eşrâf, VI, 371; İsmail Yiğit, "Tevvâbîn", Türkiye Diyanet Vakfi İslam Ansiklopedisi, (İstanbul: Türkiye Diyanet Vakfi, 2012), XLI, 50.

89 Belâzürî, Ensâbü'l-eşrâf, VI, 373.

90 İbn Sa‘d, et-Tabakâtü'l-kübrâ, IV, 293.
} 
Bu belirsizlikten olsa gerek kaynakların bir kısmında da Abdülmelik b. Mervân halife olarak kabul ediliyor. Nitekim bir rivayete göre Husayn, zafer haberini Edhem b. Muhriz ile Abdülmelik b. Mervân'a gönderdi. Haberi alan Abdülmelik minbere çıkıp bir fitne olarak gördüğü bu insanlardan kendisini kurtardı̆̆ 1 için Allah'a hamd etti. ${ }^{91}$

\section{Muhtar es-Sekafî İsyanı ve Husayn'ın Öldürülmesi}

Aynü'l-Verde savaşından sonra Husayn b. Nümeyr, Ubeydullah b. Ziyâd ile birlikte Irak üzerine yürümeye devam etti. Bu esnada Muhtar esSekafî Abdullah b. Zübeyr'in Kûfe Valisini bertaraf etmiş ve Hz. Hüseyin'in intikamını almak hedefiyle insanlardan biat almıştı. Meşruiyetini sağlamak için de Hz. Ali'nin Resulullah'ın soyundan olmayan oğlu Muhammed b. Hanefiyye' nin kendisini emir tayin ettiğini iddia etti. İslam tarihinde ilk defa olmak üzere hare ketini daha çok Emevîler tarafından ihmal edilen hatta küçümsenen mevâlîye dayandırdı. Aynı zamanda Arapların desteğini almak için Kûfe'de hatırı sayılır isimlerinden İbrahim b. Eşter'i de Muhammed b. Hanefiyye' nin ağzından yazılan bir mektupla ikna etti. ${ }^{92}$

Muhtar es-Sekafî, İbrâhim b. Eşter ile birlikte 14 Rebîülevvel 66/19 Ekim 685 tarihinde ana gayesini Hz. Hüseyin'in intikamını almak şeklinde ilan ettikleri Irak merkezli bir isyan başlattılar. İsyandan kısa bir süre sonra Kûfe Emevîler'in elinden alındı. Ancak tam bu esnada Muhtâr'ın Musul Valisi olan Abdurrahman b. Saîd, Emevî kumandanlarından Ubeydullah b. Ziyâd'ın bölgeye geldiğini, bu yüzden Tikrit'e çekilmek zorunda kaldığını bildirdi. Henüz Kûfe'deki vaziyete tam hâkim olamayan Muhtar, Yezîd b. Enes kumandasında bir orduyu Musul'a gönderdiyse de Nusaybin'de Emevî ordusuyla karşılaşan bu ilk ordu Ubeydullah'a mağlup olmaktan kurtulamad1. ${ }^{93}$ Bunun üzerine Muhtar, Kûfe'yi kontrol altına aldiktan sonra İbrahim b. Eşter komutasındaki bir orduyu Irak'a dönmekte olan Ubeydullah b. Ziyâd'ın üzerine gönderdi. Muhtar, İbrahim'in Ubeydullah ya da Husayn'dan birini öldürmeden gelmemesini istemişti. ${ }^{94}$ Çünkü Muhtar için Ubeydullah ya da Husayn'dan birinin öldürülmesi bir prestij meselesi idi aynı zamanda. Eğer bu hedefi gerçekleştirebilirse Kûfe' de çok daha rahat ve bağımsız hareket edebilecekti. ${ }^{95}$

\footnotetext{
91 Belâzürî, Ensâbü'l-eşrâf, VI, 373.

92 İbn Sa'd, et-Tabakâtü'l-kübrâ, V, 99.

3 Dîneverî, el-Ahbârü't-tıvâl, 293.

4 Dîneverî, el-Ahbârü't-tıvâl,293.

95 Söylemez, Kûfe 'nin Siyasî Tarihi, 206.
} 
İki taraf Musul civarındaki Hâzir nehri kıyısında karşılaştı. Ordular karşılıklı saf düzeni alınca karşılıklı olarak birbirlerine aşağılayıcı sözler ve davalarının haklılı̆̆ını iddia eden cümleler kurdular. ${ }^{96}$ Husayn b. Nümeyr bu savaşta Ubeydullah'ın ordusunun sağ kanadını komuta ediyordu. ${ }^{97}$ Savaş başlayınca Husayn b. Nümeyr başarılı hamleler yaparak Muhtar ordusunu gerilettiyse de İbrahim b. Eşter'in çabaları savaşın seyrini Emevîler'in aleyhine döndürdü ve Ubeydullah ile beraberindeki Husayn b. Nümeyr ağır bir hezimete uğradı. (9 Muharrem 67/5 Ağustos 686) Başta Ubeydullah b. Ziyâd, Ömer b. Sa'd ${ }^{98}$ ve Husayn b. Nümeyr olmak üzere Hz. Hüseyin'in şehit edilmesinde rolü olduğu düşünülen pek çok kişi bu savaşta öldürüldü. ${ }^{99}$ Husayn'ı da Tağlib kabilesinden Şerîk b. Cerîr öldürdü. ${ }^{100}$ Şerîk b. Cerîr daha önce Hz. Ali ordusunda savaşmış bir kimseydi. Hz. Ali'den sonra Kudüs'e yerleşmişti. Hz. Hüseyin'in şehadeti üzerine onun intikamını almaya ya da bu uğurda ölmeye and içmiş ve kalkıp Kûfe'ye gelerek Muhtar'a biat etmişti. ${ }^{101}$

İbrahim b. Eşter, Husayn ve diğerlerinin başlarını Muhtar'a gönderdi. Muhtar da bu kesik başları Mekke'de bulunan Muhammed b. Hanefiyye'ye ulaştırdı. Mekke'ye getirilen Emevî komutanlarının başları Mescid-i Haram'ın kapısında bir yerde mızrağa dikildi. ${ }^{102}$

\section{Sonuç}

Emevîler, Irak bölgesi başta olmak üzere egemen oldukları topraklarda sık sık isyanlarla karşılaşmışlardır. Bu isyanların bastırılmasında zaman zaman isyan eden bölge halkına maaşların ödenmemesi ya da onların yönetim kademelerinden uzak tutulması gibi yumuşak tedbirlere başvurulmuşsa da genellikle kanlı müdahalelerle isyanların bastırılması yoluna gidilmiştir. Söz konusu isyanların bastırılması sırasında ön plana çıkan bazı isimler Emevîler'in iç siyasî hadiselerdeki askerî başarılarının mimarları olmuşlardır. Bu bağlamda Yezîd döneminin en önemli figürlerinden birinin Husayn b. Nümeyr gibi sert bir asker olması şaşırtıcı değildir.

Belâzürî, Ensâbü'l-eşrâf, VI, 425.

İbn Miskeveyh, Tecâribu'l-ümem, I, 194.

98 Ömer b. Sa'd'ın Muhtar tarafından Kûfe'deki evinde öldürüldüğüne dair rivayetler de bulunmaktadır. Dineverî, el-Maarif, 243.

99 el-Makdisî, el-Mutahhar b. Tahir, el-Bed've't-tarih, VI, 21.

100 Belâzürî, Ensâbü'l-eşrâf, VI, 426; Hüseyin b. Muhammed b. el-Hasen Diyarbekrî, Tarihu'l-hamîs (Beyrut: Daru Sadır, tsz.), II, 309; Taberî, Tarihü 't-Taberî, VI, 90.

101 İbn Miskeveyh, Tecâribu'l-ümem, II, 196.

102 İbn Habib, el-Muhabber, 491. 
Husayn'ın, Emevî yöneticileri ile kurduğu menfaat eksenli bağlılık, kabilesinin sahip olduğu askerî kapasite nedeniyle Şam yönetimine güç vermiştir. Bu karşılıklı fayda ilişkisi çok zorlu sınanmalara rağmen devam etmiştir. Kerbelâ, Harre ve Mekke kuşatması gibi Emevî Devleti'ne yönelik başkaldırılarda Emevî kuvvetlerinin içinde yer alan Husayn b. Nümeyr'in bu olaylardaki rolü Emevî Devletinin kaderi ile kendi kaderini bir gördüğünü göstermektedir. Nitekim Husayn'ın akıbeti de bu düşünceyi doğrulamış ve Iraklılar Emevîler için besledikleri duyguları Husayn için de beslemişlerdir. Bir anlamda Ubeydullah b. Ziyâd ve Şemr b. Zilcevşen ile birlikte Husayn b. Nümeyr'e düşman olmak Emevîler'e düşman olmakla eş anlamlı hale gelmiştir. Dolayısıyla Irak merkezli her isyan hareketinin ilk hedeflerinden birisi Husayn b. Nümeyr olmuştur. Öncelikle Tevvabîn mensuplarının saldırılarına hedef olan Husayn bu savaştan kurtulduysa da Muhtar es-Sekafî́nin gönderdiği ordu tarafından öldürülmüştür.

Husayn b. Nümeyr, kendinden önceki Ziyad b. Ebîh, kendi dönemindeki Ubeydullah b. Ziyad ve sonraki dönemde Irak valiliği yapacak olan Haccac b. Yusuf gibi Emevî valileri ile karakteristik bazı ortak özellikler ortaya koymuştur. Bunlar, Emevî Devleti'ne başkaldıranlara karşı tavizsiz ve katı bir tutum, kişisel ve kabilevî menfaatlerini Emevîler'in menfaatinden ayrı düşünmemek ve isyan edenlerin kimliğinden bağımsız olarak onlara karşı salt bir asker olarak hareket etmek şeklinde sıralanabilir. Husayn b. Nümeyr tipolojisi, kısa vadede isyanların bastırılmasını sağlamışsa da uzun vadede Emevî devletinin halk desteğini büyük ölçüde yitirmesine yol açmıştır.

\section{Kaynakça}

Akbaş, Mehmet. “Ölü Bedenlere Kasdetme Girişimi Olarak İslam Tarihinde İlk Baş Kesme Hadisesinin Ortaya Çıkışı ve Emevîler Döneminde Başları Kesilenler". Harran Üniversitesi İlahiyat Fakültesi Dergisi 21/36 (2016): 112127.

Apak, Adem. "Emevîlerin Irak Siyaseti". Uludağ Üniversitesi İlahiyat Fakültesi Dergisi 18/1 (2009): 103-128.

İslâm Siyaset Geleneğinde Amr b. el-Âs. Ankara: Ankara Okulu Yayınları, 2001.

“Kerbelâ Hadisesi'nin Siyasî Sebebi Yezîd b. Muaviye'nin Veliaht Tayin Edilmesi Meselesi Üzerine Tespit ve Değerlendirmeler". Çeşitli Yönleriyle Kerbela Uluslararası Kerbela Sempozyumu, Sivas, 2010, ed. Alim Yildı, Ali Aksu, Asitan Yayıncılık, (Sivas:2010), I, 269-276. 
Atar, Fahrettin. "Noter". Türkiye Diyanet Vakfi İslam Ansiklopedisi, İstanbul: Türkiye Diyanet Vakf1, 2007,XXXIII, 210-213.

el-A‘zamî, M. Mustafa. Küttâbu'n-Nebi. Beyrut: el-Mektebü’l-İslamî, 1978.

Belâzürî, Ahmed b. Yahyâ b. Câbir b. Dâvûd. Ensâbü'l-eşrâf. thk. Süheyl Zekkar ve Riyâd Zirikli. 13 Cilt. Beyrut: Dârü'l-Fikr, 1996.

Fütûhu'l-büldân. Beyrut: Daru'l-Mektebeti'l-Hilal, 1988.

Buhârî, Muhammed b. İsmâîl b. İbrâhîm. et-Tarihü'l-kebîr. 8 Cilt. Haydarabad: Dairetü'l-Maarif el-Osmaniyye, tsz.

Demircan, Adnan. Ali-Muaviye Kavgası. İstanbul: Beyan Yayınları, 2014.

Dîneverî, Ebû Hanife Ahmed b. Dâvûd b. Venend. el-Ahbârü't-tıvâl. Kahire: Daru İhyai'l-Kütübi'l-Arabî, 1960.

Dineverî, Ebu Muhammed Abdullah b. Müslim b. Kuteybe. el-Maarif. el-Hey'etü'lMisriyye el-Amme li'l-Kütüb, 1992.

Diyarbekrî, Hüseyin b. Muhammed b. el-Hasen. Tarihu'l-hamîs. Beyrut: Daru Sadır, tsz.

Ebu Cafer el-Bağdadî, Muhammed b. Habib. el-Münemmak fi ahbâri Kureyş. Beyrut: Alemu'l-Kütüb, 1985.

Ebü'l-Arab, Muhammed b. Ahmed b. Temim el-Mağribî. el-Mihan. Riyad: Daru'1Ulum, 1984.

el-Ezrakî, Ebü'l-Velîd Muhammed b. Abdullah. Ahbâru Mekke. 2 Cilt. Beyrut: Daru'1Endelüs, tsz.

Hayyat, Ebû Amr Halife b. Hayyat eş-Şeybani. Tarihu Halife b. Hayyat. Dımaşk, Beyrut: Daru'l-Kalem, 1976.

İbn Asakir, Ebü'l-Kâsım Sikatüddin Ali b. Hasan b. Hibetullah. Târîhu Dımaşk. Beyrut: Dârü'l-Fikr, 1995.

İbn Habib, Muhammed b Habib b Ümeyye. el-Muhabber. Beyrut: Daru'1-Afakai'1Cedide, tsz.

İbn Hacer el-Askalanî, Ebû'l-Fadl Ahmed b. Ali b. Muhammed. Tehzîbu't-tehzîb. 12 Cilt. Hind: Matbaatü Daireti'l-Maarif en-Nizamiyye, 1908.

İbn Hadîde, Ebû Abdullah Muhammed b. Ali b. Ahmed b. Hadide el-Ensârî. elMisbâhüll-mudi' fi küttâbi'n-Nebiyyi'l-Ümmî ilâ mülûki'l-arzi min arabi ve acemi. 2 Cilt. Beyrut: Alemu'l-Kütüb, tsz.

İbn Hazm, Ebu Muhammed Ali b. Ahmed b. Said el-Endelüsî. Cemheretü ensâbi'l-arab. Beyrut: Daru'1-Kütübü'l-İlmiyye, 1983.

İbn Hibban, Muhammed b. Hibban b. Ahmed. es-Siretü'n-Nebeviyye ve ahbâru'l-Hulefa. 2 Cilt. Beyrut, 1997.

İbn İshak, Ebu Abdullah Muhammed. Siretu İbn İshak. Beyrut: Daru'l-Fikr, 1978. 
İbn Kesir, Ebü'l-Fida İmadüddin İsmail b. Ömer. el-Bidâye ve'n-nihaye. 15 Cilt. Daru'1Fikr, 1986.

İbn Miskeveyh, Ebû Ali Ahmed b. Muhammed b. Yakub İbn. Tecâribü'l-ümem ve te 'âkibü'l-himem. 7 Cilt. Tahran: Suruş, 2000.

İbn Sa'd, Ebû Abdullah Muhammed b. Sa'd b. Meni' ez-Zührî. el-Cüz'ü'l-mütemmim li't-tabakâti İbn Sa'd. 2 Cilt. Taif: Mektebetü's-Sadik, 1993.

.et-Tabakâtü'l-Kübrâ. 8 Cilt. ; Beyrut : Dâru Sadır, 1968.

İbnü'l-Cevzi, Cemalüddin Ebu'l-Ferec Abdurrahman b. Ali. el-Muntazam fi Tarihi'lmülûk ve'l-ümem 19 Cilt. Beyrut: Darü'l-Kütübü'l-İlmiyye, 1992.

İbnü'l-Esîr, İzzüddîn Alî b. Muhammed b. Muhammed eş-Şeybânî el-Cezerî. El-Kamil fi't-tarih. 10 Cilt. Beyrut: Daru'1-Kitabi'l-Arabi, 1997.

Kılıç, Ünal. "Harre Vakasının Sebepleri Hakkında Bazı Mülahazalar". Cumhuriyet Üniversitesi İlahiyat Fakültesi Dergisi, IV (2000): 317-24.

Küçükaşçı, Mustafa Sabri. "Savâif". Türkiye Diyanet Vakfi İslam Ansiklopedisi, İstanbul: Türkiye Diyanet Vakfı, 2009, XXXVI, 185-86.

el-Makdisî, el-Mutahhar b. Tahir. el-Bed' ve't-tarih. 6 Cilt. Port Said: Mektebetü'sSekafetü'd-Diniyye, tsz.

Makrîzî, Ebü'l-Abbâs Takıyyüddîn Ahmed b. Alî. Imtâ 'u'l-esmâ' bimâ li'r-Resûl mine'lebnâ'i (enbâ'i) ve'l-ahvâl ve'l-hafede ve'l-metâ'. 15 Cilt. Beyrut: Dârü'lKütübi'l-İlmiyye, 1999.

Meçhul, Thk. Abdulaziz ed-Durî. Ahbâru Devleti'l-Abbasiyye. Thk. Abdulaziz ed-Durî, Abdülcebbar Muttalibi. 1 c. Beyrut: Daru't-Talî’a, ts.

Meçhul, Ahbâru devleti'l-Abbasiyye, Beyrut: Daru't-Talî́a, tsz.

Nîsâbûrî, Ebû Abdillâh Muhammed b. Abdillâh b. Muhammed el-Hâkim. elMüstedrek. 4 Cilt. Beyrut: Daru'l-Kütübü'l-İlmiyye, 1990.

Öz, Şaban. “İktidar Aracı Olarak Kan Talebi Olgusunun Hz. Osman-Hz. Hüseyin Perspektifinde Karşılaştırmalı Bir Analizi”. Çeşitli Yönleriyle Kerbela Uluslararası Kerbela Sempozyumu, Sivas, 2010, ed. Alim Yıldiz, Ali Aksu, Asitan Yayınc1lık, Sivas:2010, I, 277-294.

Özaydın, Abdülkerim. "Aynülverde Savaşı". Türkiye Diyanet Vakfi İslam Ansiklopedisi. İstanbul: Türkiye Diyanet Vakfı, 1991, IV, 283.

Sarıcık, Murat. "Kerbelâ Olayında el-Hurr b. Yezîd ve Hz. Hüseyin'le Mücadelesi”. Süleyman Demirel Üniversitesi İlahiyat Fakültesi Dergisi, 2 (1995): 103-148.

Seâlibî, Ebû Mansur Abdülmelik b. Muhammed b. İsmail. Fıkhu'l-luga ve sırrü'larabiyye. Beyrut: İhyâu Turasi'l-Arabi, 2002.

Söylemez, Mehmet Mahfuz. Bedevîlikten Hadariliğe Kûfe. Ankara: Ankara Okulu Yayınları, 2015. 
Kûfe'nin Siyasî Tarihi. Ankara: Ankara Okulu Yayınları, 2015.

Taberî, Ebû Cafer İbn Cerir Muhammed b. Cerir b. Yezîd. Tarihü't-Taberî. 15 Cilt. Beyrut: Daru't-Türas, 1967.

Temir, Hakan. Emevîlerde Valilik. Kahramanmaraş: Samer Yayınları, 2019.

Vekî', Ebû Bekir Muhammed b. Halef. Ahbâru'l-kudât. 3 Cilt. Misır: el-Mektebetü'tTicariyyeti'l-Kübra, 1947.

Yiğit, İsmail. “Tevvâbîn”. Türkiye Diyanet Vakfi İslam Ansiklopedisi, İstanbul: Türkiye Diyanet Vakf1, 2012, XLI, 49-50.

Yüksel, Ahmet Turan. "Kerbelâ Vak'ası'nda Ubeydullah b. Ziyâd'in Rolü". Çeşitli Yönleriyle Kerbela Uluslararası Kerbela Sempozyumu, Sivas, 2010, ed. Alim Yıldız, Ali Aksu, Asitan Yayıncılık, Sivas:2010, I, 317-23.

Zehebî, Ebû Abdullah Şemseddin Muhammed b Ahmed b Osman. Tarihü'l-İslâm ve vefeyatü'l-meşâhir ve'l-a'lâm. 15 Cilt. Beyrut: Daru'l-Kitabi'l-Arabi, 1993. 
Doi: 10.34247/artukluakademi.886774 | Araştırma Makalesi

\section{Fatih Zengin}

Husayn ibn Numayr as-Sakuni al-Kindi as a Umayyad Commander Typology

Citation/C: Zengin, Fatih, Husayn ibn Numayr as-Sakuni al-Kindi as a Umayyad Commander Typology, Artuklu Akademi, 2021/8 (1),1-27.

\section{Extended Abstract}

Husayn ibn Numayr as-Sakuni was one of the prominent politicians and soldiers of the Umayyad period. He used to be in the service of the Umayyad State as of the tenure period of Muawiya ibn Abu Sufyan. The Homs camp of the Umayyads used to consist of Sakun, a branch of the Kindah tribe led by Husayn ibn Numayr. This army did the summer expeditions against Byzantium, also fought with people and groups opposing the Umayyad state when needed.

In the sources of Islamic history, the first activity of Homsians under the command of Husayn ibn Numayr is their fight against Ali in the Battle of Siffin. Husayn ibn Numayr took part in the conquest movements after Siffin until Yazid period. Increasing internal unrest and widening opposition during Yazid period brought along some conflicts. Husayn b. Numayr were involved in almost all of these conflicts. The Karbala incident, the Harra incident, the siege of Abdullah ibn Zubayr in Mecca, the Tawwabun movement and the revolts of Mukhtar al-Sekafi are the events that as- Sakuni fought as a commander at the head of his army by the Umayyads.

Yazid's seizure of the caliphate caused reactions in many places, especially in Hejaz and Iraq. In particular, Iraqis turned their reaction into action and invited Husayn ibn Ali to Kufa to pay allegiance to him. Thereupon, Yazid appointed Ubeydullah ibn Ziyad as the governor of Kufa. Ubeydullah took drastic measures against Husayn ibn Ali, who set off from Mecca upon the invitation of settlers of Kufa. The one who put these measures into practice was Husayn ibn Numayr appointed by Ubeydullah to head the Kufa security organization. Husayn ibn Numayr surrounded the region with an army of four thousand men. Thus, he disconnected Husayn from the Kufa and forced him to head towards Karbala. An army formed from the people of Kufa under the command of Omar ibn Saad came to Karbala and prevented Husayn bin Ali from moving forward. Most of Husayn's party was martyred in the clash that took place there. The first attack on Husayn who was left alone was the one that Husayn b. Numayr did.

The brutal murder of Husayn in Karbala caused indignation among Muslims. This incident triggered a series of events. The first of the chain events caused by the martyrdom of Husayn is the uprising that started in Medina. The people of Medina, who were opposed to Yazid administration for a long time, hardened their opposition with Karbala incident and declared that they did not recognize the caliphate of Yazid. Yazid sent an army under Muslim ibn Ukbah command against this movement led by Abdullah ibn Hanzalah and appointed Husayn ibn Numayr as the second command of the army. The Umayyad army was 
victorious in the war that took place in a place called al- Harrah, just outside Medina, and it was subjugated to the people of Medina.

Another opponent who didn't accept accept Yazid's caliphate is Abdullah ibn Zubayr. He rebelled against the Umayyads by declaring his own caliphate in Mecca after Husayn was martyred in Karbala. For this reason, after al- Harra incident, Yazid's army marched on Abdullah ibn Zubeyr, the main target. After Muslim's death on the way, Husayn b. Numayr took command of the army. The army under Husayn's command besieged Mecca to ensure Abdullah's obedience to Yazid. During this siege, the Kaaba was damaged due to catapult stones thrown into the city. This incident was deemed one of the faults of Yazid and Husayn ibn Numayr. The Umayyad army returned to Damascus upon the death of Yazid during the siege.

Marwan ibn Hakem was elected the Umayyad caliph due to the pressure of rulers of Yazid period, including Husayn ibn Numayr. In the period of Marwan ibn Hakem, internal turmoil did not end. The Battle of Marj Rahit (634 CE) took place after the people of Damascus did not accept the new caliph. Husayn and the people of Homs played an important role in the victory of Marwan's side in this war. Meanwhile, those who regretted and repented for leaving Hussein alone without help in Karbala started a new uprising in Kufa. This group, led by Solomon one of the companions of the prophet, first went to Karbala and visited Huseyin's grave. Then they marched on Ubeydullah, who was coming from Syria towards Iraq. The two armies met in the place called Ayn alWardah. The war ended with the killing of most of the members of Tawwabun. Husayn ibn Numayr personally commanded the army in Aynu'l-Wardah war.

Another name who started the rebellion movement due to the martyrdom of Hüseyin is Muhtar al-Sekafî. The Mukhtar, who gathered men from the people of Kufa in order to avenge Hüseyin, based his movement mostly on Mevalis. He also legitimized his initiative by saying that he got permission from Muhammad ibn Hanafiyyah. He pointed out that the main purpose of the rebellion was the killing of those involved in the Karbala incident such as Ubeydullah, Husayn and Şemr. Although the first military unit sent by the Mukhtar against Ubeydullah was defeated, an army sent under the command of Ibrahim ibn Ashtar defeated the Umayyad army near Mosul on the banks of the river. Husayn ibn Numayr was killed along with Ubeydullah in this war.

Husayn b. Numayr served faithfully to the Umayyad state throughout his life. However, it is not possible to explain this loyalty of him only with his faith or trust in them. Protecting the interests of as- Sakunites who settled around Homs in particular, and taking advantage of the opportunities provided by the Umayyad state, as in the expeditions on Anatolia or elsewhere, were also important motivations for him to act together with the Umayyads 